\title{
WORK-RELATED OUTCOME AFTER ACUTE CORONARY SYNDROME: IMPLICATIONS OF COMPLEX CARDIAC REHABILITATION IN OCCUPATIONAL MEDICINE
}

\section{MONICA LAMBERTI ${ }^{1}$, GENNARO RATTI ${ }^{2}$, DONATO GERARDI ${ }^{1}$, CRISTINA CAPOGROSSO ${ }^{2}$, GIANFRANCO RICCIARDI ${ }^{3}$, COSIMO FULGIONE ${ }^{3}$, SALVATORE LATTE $^{3}$, PAOLO TAMMARO ${ }^{2}$, GREGORIO COVINO ${ }^{2}$, ALBERT NIENHAUS ${ }^{4,5}$, ELPIDIO MARIA GARZILLO ${ }^{1}$, MARIO MALLARDO ${ }^{3}$, and PAOLO CAPOGROSSO ${ }^{2}$}

${ }^{1}$ Second University of Naples, Naples, Italy

Department of Experimental Medicine, Section of Hygiene, Occupational Medicine and Forensic Medicine,

School of Medicine

${ }^{2}$ S. Giovanni Bosco Hospital, Naples 1 Local Health Unit, Naples, Italy

Cardiology/Intensive Care Unit

${ }^{3}$ S. Gennaro Hospital, Naples 1 Local Health Unit, Naples, Italy

Cardiology/Cardiac Rehabilitation

${ }^{4}$ University Medical Center Hamburg-Eppendorf, Hamburg, Germany

Institute for Health Services Research in Dermatology and Nursing

${ }^{5}$ Institution for Statutory Accident Insurance and Welfare Services, Hamburg, Germany

Department of Occupational Health Research

\begin{abstract}
Objectives: Coronary heart disease is frequent in the working-age population. Traditional outcomes, such as mortality and hospital readmission, are useful for evaluating prognosis. Fit-for-work is an emerging outcome with clinical as well as socioeconomic significance. We describe the possible benefit of a cardiac rehabilitation (CR) program for return to work (RTW) after acute coronary syndrome (ACS). Material and Methods: We evaluated 204 patients with recent ACS. They were divided into 4 groups on the basis of their occupational work load: very light (VL), light (L), moderate $(\mathrm{M})$, and heavy $(\mathrm{H})$. Work-related outcomes were assessed with the Work Performance Scale (WPS) of the Functional Status Questionnaire and as "days missed from work" (DMW) in the previous 4 weeks. The variables considered for outcomes were percent ejection fraction, functional capacity expressed in metabolic equivalents (METs), and participation or non-participation in the CR program (CR+ and CR-). Results: One hundred thirty (66\%) patients took part in the CR program. Total WPS scores for CR+ and CR- subgroups were VL group: $18 \pm 4$ vs. $14 \pm 4$ ( $<<0.001)$, L group: $18 \pm 3$ vs. $14 \pm 3$ ( $p<0.0001)$, M group: $19 \pm 3$ vs. $16 \pm 3$ ( $p<0.003$ ), and H group: $20 \pm 4$ vs. $17 \pm 3$ ( $p<0.006$ ). Fewer DMW were reported by the CR+ group. Conclusions: Non-participation in CR was a consistent cause of poorer work-related outcomes. Our findings indicate that $\mathrm{CR}$ and occupational counseling play a very important role in worker recovery and subsequent reintegration in the workplace, in particular among clerical workers.
\end{abstract}

Key words:

Depression, Rehabilitation, Workers, Acute coronary syndrome, Counseling, Anxiety

Received: March 23, 2015. Accepted: July 31, 2015.

Corresponding author: M. Lamberi, Second University of Naples, Department of Experimental Medicine, Section of Hygiene, Occupational Medicine and Forensic Medicine, School of Medicine, De Crecchio 13, 80100 Naples, Italy (e-mail: monica.lamberti@unina2.it). 


\section{INTRODUCTION}

Coronary heart disease (CHD) is the main cause of death worldwide, accounting for $31 \%$ of mortality [1]. In fact, in the working population (aged $<65$ ), CHD is the single most important cause of death in men, and in women it is preceded only by breast cancer [2-3]. It is both a medical and a socio-economic problem.

Returning to work after a coronary event produces economic benefits for the community and patients alike, improving the quality of life of their families too [4-5]. It is generally recognized that the return to work is not a simple function of clinical status and the workplace, but is also influenced by psychological factors, such as anxiety and depression [6]. In CHD patients, cardiac rehabilitation (CR) has a strong potential to improve occupational outcome [7-10]. Currently, "complex CR" consists of several elements, including pharmacological and nutritional management, motor rehabilitation, and behavioral counseling, to effectively manage CHD risk factors and promote favorable lifestyle changes [11]. Although the role of occupational medicine is clear for primary prevention, employability is often difficult to evaluate in secondary prevention, requiring an accurate evaluation of clinical and occupational factors [12].

The aim of this study was to evaluate work-related outcomes in cardiac patients at 6 months from acute coronary syndrome (ACS), identifying related individual, clinical, and interventional factors.

\section{MATERIAL AND METHODS}

We enrolled 204 working-age acute coronary syndrome (ACS) patients (Table 1-3). We asked all subjects to participate in a complex cardiac rehabilitation program that included exercise prescription, exercise training, instruction on medications, and lifestyle changes such as the cessation of smoking. The patients participating in the CR program received supervised exercise training and counseling: the exercise session included stretching, resistance training, and aerobic exercise. The education and counseling session (four 50-min counseling sessions for 1 month) consisted of advice on healthy nutrition, physical activity, maintaining a healthy body weight, and issues related to quitting smoking and alcohol consumption. Exclusion criteria were age $>65$ years, severe concomitant non-cardiac diseases such as cancer, renal dysfunction (serum creatinine $>3 \mathrm{mg} / \mathrm{dl}$ ), liver dysfunction (alanine aminotransferase/aspartate aminotransferase $>1.5$ times the upper normal limit), and dementia, any systemic disease limiting exercise, and inability to participate in a prospective study for logistical reasons.

The average energy requirement for the patients' work activities was estimated with the aid of pre-existing, specific tables [13] that classify the various tasks on the basis of metabolic equivalents (METs): < 3 METs - very

Table 1. Characteristics of patients with recent acute coronary syndrome (ACS)

\begin{tabular}{|c|c|}
\hline Characteristic & $\begin{array}{c}\text { Patients } \\
(\mathrm{N}=204)\end{array}$ \\
\hline Age [years] $(\mathrm{M} \pm \mathrm{SD})$ & $51 \pm 8$ \\
\hline \multicolumn{2}{|l|}{$\operatorname{Sex}[n]$} \\
\hline male & 199 \\
\hline female & 5 \\
\hline \multicolumn{2}{|l|}{ Education [n (\%)] } \\
\hline primary/secondary & $119(59)$ \\
\hline high school & $78(38)$ \\
\hline university & $7(3)$ \\
\hline \multicolumn{2}{|l|}{ Professional category [n (\%)] } \\
\hline clerical & $75(37)$ \\
\hline manual & $126(62)$ \\
\hline managerial & $3(1)$ \\
\hline \multicolumn{2}{|l|}{ Type of intervention [n (\%)] } \\
\hline PTCA & $189(93)$ \\
\hline only medical therapy & $15(7)$ \\
\hline cardiac rehabilitation & $134(66)$ \\
\hline
\end{tabular}

$\mathrm{M}$ - mean; SD - standard deviation.

PTCA - percutaneous transluminal coronary angioplasty. 
Table 2. Characteristics of patients with recent acute coronary syndrome (ACS) stratified by work energy requirement

\begin{tabular}{|c|c|c|c|c|}
\hline \multirow[b]{2}{*}{ Variable } & \multicolumn{4}{|c|}{ Group } \\
\hline & $\begin{array}{c}\mathrm{VL} \\
(<3 \mathrm{MET})\end{array}$ & $\begin{array}{c}\mathrm{L} \\
(3-5 \mathrm{MET})\end{array}$ & $\begin{array}{c}\mathrm{M} \\
\text { (5-7 MET) }\end{array}$ & $\begin{array}{c}\mathrm{H} \\
(>7 \mathrm{MET})\end{array}$ \\
\hline Patients [n (\%)] & $78(38)$ & $61(30)$ & $36(17)$ & $29(15)$ \\
\hline Age [years] $(\mathrm{M} \pm \mathrm{SD})$ & $54 \pm 6$ & $55 \pm 6$ & $48 \pm 6$ & $42 \pm 5$ \\
\hline \multicolumn{5}{|l|}{$\operatorname{Sex}[n]$} \\
\hline male & 73 & 61 & 36 & 29 \\
\hline female & 5 & 0 & 0 & 0 \\
\hline \multicolumn{5}{|l|}{ Type of intervention [n (\%)] } \\
\hline PTCA & $71(91)$ & $58(95)$ & $31(86)$ & $29(100)$ \\
\hline medical therapy only & $7(9)$ & $3(5)$ & $5(14)$ & $0(0)$ \\
\hline cardiac rehabilitation & $51(65)$ & $44(72)$ & $21(58)$ & $18(62)$ \\
\hline \multicolumn{5}{|l|}{ Drugs taken at 6 months $[\mathrm{n}(\%)]$} \\
\hline antiplatelet drugs & $78(100)$ & $61(100)$ & $35(97)$ & $25(86)$ \\
\hline$\beta$-blockers & $71(91)$ & $55(90)$ & $21(58)$ & $13(44)$ \\
\hline cholesterol-lowering agents & $68(87)$ & $61(100)$ & $23(64)$ & $19(66)$ \\
\hline ACE inhibitors & $55(70)$ & $44(72)$ & $18(50)$ & $11(38)$ \\
\hline
\end{tabular}

ACE - angiotensin-converting-enzyme; VL - very light; L - light; M - moderate; H - heavy; MET - metabolic equivalent. Other abbreviations as in Table 1.

Table 3. Health-related quality of life profile for each work group

\begin{tabular}{|c|c|c|c|c|c|c|c|}
\hline \multicolumn{2}{|c|}{$\begin{array}{l}\text { VL group } \\
(\mathrm{N}=78) \\
(\mathrm{M} \pm \mathrm{SD})\end{array}$} & \multicolumn{2}{|c|}{$\begin{array}{l}\text { L group } \\
(\mathrm{N}=61) \\
(\mathrm{M} \pm \mathrm{SD})\end{array}$} & \multicolumn{2}{|c|}{$\begin{array}{l}\text { M group } \\
(\mathrm{N}=36) \\
(\mathrm{M} \pm \mathrm{SD})\end{array}$} & \multicolumn{2}{|c|}{$\begin{array}{l}\text { H group } \\
(\mathrm{N}=29) \\
(\mathrm{M} \pm \mathrm{SD})\end{array}$} \\
\hline $\mathrm{CR}+$ & CR- & $\mathrm{CR}+$ & CR- & $\mathrm{CR}+$ & CR- & $\mathrm{CR}+$ & CR- \\
\hline $0.72 \pm 0.19$ & $0.55 \pm 0.23^{1}$ & $0.74 \pm 0.17$ & $0.62 \pm 0.17^{2}$ & $0.73 \pm 0.14$ & $0.62 \pm 0.16^{3}$ & $0.79 \pm 0.10$ & $0.64 \pm 0.13^{4}$ \\
\hline
\end{tabular}

"CR+" - attending cardiac rehabilitation; "CR-" - not attending cardiac rehabilitation.

Other abbreviations as in Table 1 and 2 .

${ }^{1} \mathrm{p}<0.0009 ;{ }^{2} \mathrm{p}<0.02 ;{ }^{3} \mathrm{p}<0.03 ;{ }^{4} \mathrm{p}<0.003$.

light work (VL group), 3-5 METs - light work (L group), 5-7 METs - moderate work (M group), and > 7 METs heavy work (H group).

Health-related quality of life (HRQOL), anxiety and depression, and functional status were evaluated 6 months after resumption of work. Performance status after resumption of work and work-related outcomes were also assessed. Within each group, the variable considered for work-related outcome was carrying out CR. Traditional variables considered were percent ejection fraction (EF (\%)) and functional capacity for exercise testing (expressed in METs).

All subjects taking part in the study were informed by a physician on the rationale and aims of the survey, and a written informed consent was obtained. According to Italian legislation on guidelines for observational 
studies, ethical approval for conducting this survey was unnecessary, and cross-sectional studies did not require formal approval by the local Institutional Review Boards. Personal information on the subjects taking part in the study was protected in accordance with Italian law.

\section{Health-related quality of life}

The HRQOL profile was assessed with the European Quality of Life scale 5D (EQ-5D) [14-17]. It consists of 2 components: an EQ-5D descriptive system and an EQ-5D visual analog scale (EQ-5D VAS). For the descriptive system, the respondent was asked to rate his/her health for 5 of EQ-5D dimensions, i.e., mobility, self-care, pain/discomfort, usual activities, and anxiety/depression on a 5-level scale:

- no problems,

- slight problems,

- moderate problems,

- severe problems,

- unable to perform.

Scores were transformed to produce a single index ranging from 0.59 for the worst to 1 for the best possible state of health. For the EQ-VAS, participants drew a line from a box to the point on a thermometer-like scale corresponding to their state of health (ranging from 0 "the worst imaginable state of health" to 100 "the best imaginable state of health").

\section{Anxiety and depression}

Anxiety and depression were evaluated with the Hospital Anxiety and Depression Scale (HADS) [18-19]. On this 14 -item scale, 7 relate to anxiety and 7 to depression, with responses scored 0-3 (3 indicating higher symptom frequencies). The score for each subscale (anxiety and depression) ranged $0-21$, with scores categorized as follows: normal (0-7), mild (8-10), moderate (11-14), and severe (15-21).

\section{Work performance status}

\section{and indicators of work-related outcomes}

To determine work status before and after myocardial infarction (MI), work-related outcomes (absenteeism and perceived work performance) were assessed with the Work Performance Scale (WPS) of the Functional Status Questionnaire [20-21]. The WPS score is calculated as the mean of the 6 responses ranging 1-4, with 4 being the highest level of work performance. As indicators of work-related outcomes, we used the time to return-towork (in weeks) and the days missed from work (DMW) over the previous 6 months. For work performance status, DMW was assessed by asking respondents how many days they had missed from work due to cardiovascular disease in the previous 4 weeks.

\section{Statistical analysis}

Data are expressed as mean \pm standard deviation $(\mathrm{M} \pm \mathrm{SD})$. Statistical analysis was performed with ANOVA for differences between the 4 groups, and with Student's t-test for unpaired data for differences between subgroups. A $p<0.05$ was considered statistically significant.

\section{RESULTS}

All 204 subjects enrolled in the study returned to full-time work after a variable period (1-2 months) from hospitalization. One hundred eighty nine subjects had undergone single percutaneous transluminal coronary angioplasty (PTCA), and 15 had been treated with medical therapy only. One hundred thirty $(66 \%)$ subjects participated in the complex $\mathrm{CR}$ program $(\mathrm{M} \pm \mathrm{SD}=25 \pm 10$ days after hospital discharge). There were no differences in age, gender, or level of education between $\mathrm{CR}+$ and CRsubgroups. Significant differences were found in the HRQOL profile between the CR + and the CR-subgroup for each MET work category (Table 3). For anxiety, scores were significantly different between the CR subgroups only in the VL and the L groups, whereas 
Table 4. Anxiety and depression profiles for each work group

\begin{tabular}{|c|c|c|c|c|c|c|c|c|}
\hline \multirow{3}{*}{ Score } & \multicolumn{8}{|c|}{$\begin{array}{c}\text { Group } \\
(\mathrm{M} \pm \mathrm{SD})\end{array}$} \\
\hline & \multicolumn{2}{|c|}{$\begin{array}{c}\mathrm{VL} \\
(\mathrm{N}=78)\end{array}$} & \multicolumn{2}{|c|}{$\begin{array}{c}\mathrm{L} \\
(\mathrm{N}=61)\end{array}$} & \multicolumn{2}{|c|}{$\begin{array}{c}\mathrm{M} \\
(\mathrm{N}=36)\end{array}$} & \multicolumn{2}{|c|}{$\begin{array}{c}\mathrm{H} \\
(\mathrm{N}=29)\end{array}$} \\
\hline & $\mathrm{CR}+$ & CR- & $\mathrm{CR}+$ & CR- & $\mathrm{CR}+$ & CR- & $\mathrm{CR}+$ & $\mathrm{CR}-$ \\
\hline Anxiety & $8.9 \pm 3.4$ & $12.6 \pm 4.2^{1}$ & $9.6 \pm 2.2$ & $12.0 \pm 2.9^{4}$ & $8.8 \pm 2.5$ & $10.6 \pm 2.9$ & $9.0 \pm 1.7$ & $10.0 \pm 2.8$ \\
\hline Depression & $9.0 \pm 3.2$ & $12.3 \pm 4.5^{2}$ & $9.5 \pm 2.1$ & $12.0 \pm 2.5^{5}$ & $8.7 \pm 2.7$ & $10.8 \pm 2.2^{7}$ & $8.5 \pm 2.5$ & $10.7 \pm 0.7$ \\
\hline Total & $17.9 \pm 6.4$ & $24.9 \pm 8.3^{3}$ & $19.1 \pm 4.1$ & $24.0 \pm 4.6^{6}$ & $17.5 \pm 5.1$ & $21.4 \pm 4.6^{8}$ & $17.5 \pm 3.8$ & $21.3 \pm 6.0^{9}$ \\
\hline
\end{tabular}

${ }^{1} \mathrm{p}<0.0001 ;{ }^{2} \mathrm{p}<0.00046 ;{ }^{3} \mathrm{p}<0.00011 ;{ }^{4} \mathrm{p}<0.0008 ;{ }^{5} \mathrm{p}<0.00031 ;{ }^{6} \mathrm{p}<0.00016 ;{ }^{7} \mathrm{p}<0.018 ;{ }^{8} \mathrm{p}<0.024 ;{ }^{9} \mathrm{p}<0.048$.

Abbreviations as in Table 1-3.

Table 5. Work performance status for each work group

\begin{tabular}{|c|c|c|c|c|c|c|c|c|}
\hline \multirow{3}{*}{ Score } & \multicolumn{8}{|c|}{ Group } \\
\hline & \multicolumn{2}{|c|}{$\begin{array}{c}\mathrm{VL} \\
(\mathrm{N}=78)\end{array}$} & \multicolumn{2}{|c|}{$\begin{array}{c}\mathrm{L} \\
(\mathrm{N}=61)\end{array}$} & \multicolumn{2}{|c|}{$\begin{array}{c}\mathrm{M} \\
(\mathrm{N}=36)\end{array}$} & \multicolumn{2}{|c|}{$\begin{array}{c}\mathrm{H} \\
(\mathrm{N}=29)\end{array}$} \\
\hline & $\mathrm{CR}+$ & $\mathrm{CR}-$ & $\mathrm{CR}+$ & $\mathrm{CR}-$ & $\mathrm{CR}+$ & $\mathrm{CR}-$ & $\mathrm{CR}+$ & $\mathrm{CR}-$ \\
\hline \multicolumn{9}{|l|}{ Work performance status } \\
\hline item $1(\mathrm{M} \pm \mathrm{SD})$ & $2.7 \pm 1.1$ & $2.2 \pm 1.0^{1}$ & $2.8 \pm 1.0$ & $2.1 \pm 1.1^{2}$ & $2.9 \pm 0.9$ & $2.7 \pm 1.0$ & $3.2 \pm 0.8$ & $3.3 \pm 0.6$ \\
\hline item $2(\mathrm{M} \pm \mathrm{SD})$ & $3.1 \pm 0.9$ & $2.5 \pm 0.8^{1}$ & $3.2 \pm 0.8$ & $2.5 \pm 0.7^{8}$ & $3.1 \pm 0.6$ & $2.4 \pm 0.9^{5}$ & $3.1 \pm 1.0$ & $2.4 \pm 1.1$ \\
\hline item $3(\mathrm{M} \pm \mathrm{SD})$ & $2.7 \pm 11.0$ & $2.1 \pm 1.0^{2}$ & $3.2 \pm 1.0$ & $2.2 \pm 0.7^{9}$ & $3.5 \pm 0.5$ & $3.1 \pm 0.7^{4}$ & $3.5 \pm 0.7$ & $3.0 \pm 0.8$ \\
\hline item $4(\mathrm{M} \pm \mathrm{SD})$ & $3.0 \pm 0.8$ & $2.4 \pm 0.9^{1}$ & $3.3 \pm 0.6$ & $2.5 \pm 0.9^{3}$ & $3.2 \pm 0.8$ & $2.5 \pm 0.9^{4}$ & $3.4 \pm 0.6$ & $3.0 \pm 0.7$ \\
\hline item $5(\mathrm{M} \pm \mathrm{SD})$ & $3.1 \pm 0.8$ & $2.2 \pm 1.1^{3}$ & $3.0 \pm 0.9$ & $2.5 \pm 0.7^{4}$ & $3.2 \pm 0.7$ & $2.6 \pm 0.8^{2}$ & $3.4 \pm 0.7$ & $2.8 \pm 0.8^{1}$ \\
\hline item $6(\mathrm{M} \pm \mathrm{SD})$ & $3.1 \pm 0.8$ & $2.6 \pm 0.8^{4}$ & $3.0 \pm 0.7$ & $2.5 \pm 0.8^{4}$ & $3.4 \pm 0.7$ & $2.9 \pm 0.7$ & $3.3 \pm 0.8$ & $2.8 \pm 0.7$ \\
\hline average $(\mathrm{M} \pm \mathrm{SD})$ & $3.0 \pm 0.7$ & $2.3 \pm 0.8^{5}$ & $3.1 \pm 0.5$ & $2.4 \pm 0.6^{7}$ & $3.2 \pm 0.5$ & $2.7 \pm 0.5^{10}$ & $3.3 \pm 0.6$ & $2.9 \pm 0.4$ \\
\hline total $(\mathrm{M} \pm \mathrm{SD})$ & $18.0 \pm 4.0$ & $14.0 \pm 4.0^{5}$ & $18.0 \pm 3.0$ & $14.0 \pm 3.0^{7}$ & $19.0 \pm 3.0$ & $16.0 \pm 3.0^{10}$ & $20.0 \pm 4.0$ & $17.0 \pm 3.0$ \\
\hline patients with $\geq 1 \mathrm{DMW}^{\mathrm{a}}[\mathrm{n}(\%)]$ & $4(7)$ & $7(25)^{6}$ & $5(11)$ & $6(35)^{6}$ & $1(4)$ & $2(13)$ & $1(5)$ & $1(9)$ \\
\hline \multicolumn{9}{|l|}{ Work-related outcomes } \\
\hline RTW [weeks] (M \pm SD) & $6.9 \pm 1.8$ & $8.6 \pm 1.5^{7}$ & $7.1 \pm 1.8$ & $8.4 \pm 1.6^{5}$ & $7.9 \pm 1.5$ & $8.9 \pm 1.0^{1}$ & $8.0 \pm 1.3$ & $9.1 \pm 0.9^{4}$ \\
\hline $\mathrm{DMW}^{\mathrm{b}}(\mathrm{M} \pm \mathrm{SD})$ & $7.4 \pm 4.5$ & $11.9 \pm 4.4^{5}$ & $6.8 \pm 4.8$ & $9.5 \pm 4.4^{2}$ & $5.7 \pm 3.3$ & $8.5 \pm 4.3^{2}$ & $3.0 \pm 2.9$ & $5.7 \pm 3.9^{1}$ \\
\hline
\end{tabular}

DMW - days missed from work; RTW - time of return to work. Other abbreviations as in Table 1-3.

${ }^{\mathrm{a}}$ Patients with at least $1 \mathrm{DMW}$ in the previous 4 weeks; ${ }^{\mathrm{b}}$ Days missed from work in previous 6 months.

${ }^{1} \mathrm{p}<0.04 ;{ }^{2} \mathrm{p}<0.03 ;{ }^{3} \mathrm{p}<0.0002 ;{ }^{4} \mathrm{p}<0.02 ;{ }^{5} \mathrm{p}<0.01 ;{ }^{6} \mathrm{p}<0.029 ;{ }^{7} \mathrm{p}<0.0001 ;{ }^{8} \mathrm{p}<0.007 ;{ }^{9} \mathrm{p}<0.001 ;{ }^{10} \mathrm{p}<0.003$.

differences in depression scores were always significant except in the H work group (Table 4).

Similarly, total WPS scores were significantly different between CR subgroups except in $\mathrm{H}$ workers (Table 5). The number of patients taking time off from work was lower for the CR+ subgroup in VL and L workers, but there were no significant differences in the other 2 work groups. However, the 2 work-related outcomes taken into consideration (i.e., time to return-to-work and number of days off work) were always significantly lower in patients attending CR (Table 5). No significant differences in $\mathrm{EF}(\%)$ and functional capacity for exercise were found 
Table 6. Percent ejection fractions (EF (\%)) and metabolic equivalent (MET) scores of functional capacity for exercise in each work group

\begin{tabular}{|c|c|c|c|c|c|c|c|c|}
\hline \multirow{3}{*}{ Variable } & \multicolumn{8}{|c|}{$\begin{array}{c}\text { Group } \\
(\mathrm{M} \pm \mathrm{SD})\end{array}$} \\
\hline & \multicolumn{2}{|c|}{$\begin{array}{c}\mathrm{VL} \\
(\mathrm{N}=78)\end{array}$} & \multicolumn{2}{|c|}{$\begin{array}{c}\mathrm{L} \\
(\mathrm{N}=61)\end{array}$} & \multicolumn{2}{|c|}{$\begin{array}{c}\mathrm{M} \\
(\mathrm{N}=36)\end{array}$} & \multicolumn{2}{|c|}{$\begin{array}{c}\mathrm{H} \\
(\mathrm{N}=29)\end{array}$} \\
\hline & $\mathrm{CR}+$ & CR- & $\mathrm{CR}+$ & CR- & $\mathrm{CR}+$ & CR- & $\mathrm{CR}+$ & CR- \\
\hline $\mathrm{EF}[\%]$ & $50.0 \pm 9.9$ & $51.1 \pm 6.2$ & $51.1 \pm 5.6$ & $51.4 \pm 4.8$ & $53.8 \pm 3.7$ & $53.7 \pm 4.5$ & $53.6 \pm 3.7$ & $53.7 \pm 4.6$ \\
\hline MET & $4.5 \pm 1.0$ & $4.2 \pm 1.3$ & $4.3 \pm 0.8$ & $4.4 \pm 0.7$ & $5.7 \pm 1.1$ & $6.0 \pm 1.2$ & $5.9 \pm 1.3$ & $6.2 \pm 1.4$ \\
\hline
\end{tabular}

Abbreviations as in Table 1-3.

between the CR subgroups of any of the work groups (Table 6).

\section{DISCUSSION}

Many occupational physicians base their opinion on a patient's suitability for work after a pathological event, such as ACS, on the results of a maximal exercise test performed under optimized drug therapy. However, many other factors can affect the reintegration of ACS patients into employment. In our study, we found that work performance (assessed using the WPS) was positively influenced by participation in the CR program. However, not all workers seemed to benefit: in fact, the differences found among high intensity workers (H group) did not reach statistical significance (WPS total score $=20 \pm 4$ in CR + vs. $17 \pm 3$ in CR-, $p=0.06)$. A similar trend was also found for quality of life (assessed with the EQ-5D scale): there were benefits for patients attending CR, but there was not always a statistically significant difference in scores for anxiety and depression in patients with a high work intensity (H group anxiety score: $9 \pm 1.7$ in $\mathrm{CR}+$ vs. $10 \pm 2.8$ in $\mathrm{CR}-, \mathrm{p}=0.077$; depression score: $8.5 \pm 2.5$ in $\mathrm{CR}+$ vs. $10.7 \pm 0.7$ in $\mathrm{CR}-$, $\mathrm{p}=0.062$ ).

Cardiac rehabilitation favorably affected indicators of work outcome (time to return-to-work and DMW) in all groups. Patients with a more strenuous work activity ( $\mathrm{M}$ and $\mathrm{H}$ groups) returned to work later than those with a less physically active job (VL and L groups), but in all 4 groups the patients that had undergone CR resumed work in a significantly shorter period of time. This produces a twofold benefit: the disease has lower social and economic costs, and there is a positive psychological effect caused by the recovery of the social and economic role of the patient-worker. However, workers with lighter activities (VL and L groups) took more working days off (in the 6 months after work resumption) than workers with more physically strenuous jobs ( $\mathrm{M}$ and $\mathrm{H}$ groups), despite returning earlier to work. Nevertheless, in all 4 groups, CR was again effective in achieving a reduction in working days lost due to illness.

The data obtained is consistent with evidence in the literature [22-24], according to which white-collar workers (i.e., most of the VL group) have a less favorable outcome than blue-collar workers (corresponding to groups $\mathrm{L}, \mathrm{M}$, and $\mathrm{H}$ ) in terms of the number of working days lost due to illness. This is probably attributable to a higher prevalence of anxiety and depression [25]. This finding was also reflected in the population examined by us, in which anxiety and depression scores were higher in the VL and L subgroups that did not attend CR. The counseling part of the CR program probably acts to reduce anxiety, and this effect was significant in the $\mathrm{VL}$ and $\mathrm{L}$ groups; counseling also reduced depression, an effect significant in the VL, L, and M groups.

Finally, participation in CR did not ameliorate clinical outcome, as assessed by $\mathrm{EF}(\%)$ and functional capacity to 
conduct exercise. This finding is most likely due to the use of best diagnosis and therapy in the acute phase of the disease, which have already led to reductions in mortality rates in the short term. Thus, these traditional parameters have a limited role in the evaluation of workers with heart disease attending CR programs, as suggested in the literature [26-28].

\section{CONCLUSIONS}

Our study indicates that non-participation in CR is a consistent cause of poorer work-related outcomes. Cardiac rehabilitation, and occupational counseling in particular, plays a very important role in worker recovery and subsequent reintegration into the workplace, especially for clerical workers. It may thus be beneficial to develop specific "complex CR programs" that take into account not only traditional clinical parameters (ventricular function expressed as EF (\%), and functional capacity expressed in METs), but also all occupational co-factors, such as psychosocial factors and the type of work done.

\section{Study limitations}

Our study group comprised only a small number of subjects. They were not randomized as this would have been ethically unacceptable: indeed, it is well known that participation in a complex $\mathrm{CR}$ program reduces mortality and prevents recurrence of ACS, as previously described in others studies [24]. Also, it was not possible to conduct our study for more than 6 months after resumption of work. Future trials will be needed to assess the efficacy of supervised exercise training over a longer period.

\section{REFERENCES}

1. Mendis S, Puska P, Norrving B. Global atlas on cardiovascular disease prevention and control. Geneva: World Health Organization; 2011.

2. Lloyd-Jones D, Adams R, Carnethon M, de Simone G, Ferguson TB, Flegal K, et al. Heart disease and stroke statistics - 2009 update: A report from the American Heart Association Statistics Committee and Stroke Statistics Subcommittee. Circulation. 2009;119(3):e21-181, http://dx.doi. org/10.1161/CIRCULATIONAHA.108.191261.

3. Go AS, Mozaffarian D, Roger VL, Benjamin EJ, Berry JD, Borden WB, et al. AHA statistical update. Heart disease and stroke statistics - 2013 update: A report from the American Heart Association. Circulation. 2013 Jan 1;127(1):e6-245. http://dx.doi.org/10.1161/CIR.0b013e31828124ad.

4. Mital A, Desai A. Return to work after a coronary event. J Cardiopulm Rehabil. 2004;24:365-73, http://dx.doi. org/10.1097/00008483-200411000-00001.

5. Bhattacharyya MR, Perkins-Porras L, Whitehead DL, Steptoe A. Psychological and clinical predictors of return to work after acute coronary syndrome. Eur Heart J. 2007;28(2): 160-5, http://dx.doi.org/10.1093/eurheartj/ehl440.

6. O'Neil A, Sanderson K, Oldenburg B. Depression as a predictor of work resumption following myocardial infarction (MI): A review of recent research evidence. Health Qual Life Outcomes. 2010;8:95, http://dx.doi.org/10.1186/1477-7525-8-95.

7. Leon A, Franklin B, Costa F, Balady G, Berra K, Steart K, et al. Cardiac rehabilitation and secondary prevention of coronary heart disease: An American Heart Association scientific statement from the Council on Clinical Cardiology (Subcommittee on Exercise, Cardiac Rehabilitation, and Prevention) and the Council on Nutrition, Physical Activity, and Metabolism (Subcommittee on Physical Activity), in collaboration with the American Association of Cardiovascular and Pulmonary Rehabilitation. Circulation. 2005;111:369-76, http://dx.doi.org/10.1161/01. CIR.0000151788.08740.5C.

8. Oldridge NB, Guyatt GH, Fischer ME, Rimm AA. Cardiac rehabilitation after myocardial infarction. Combined experience of randomized clinical trials. JAMA. 1988;260:945-50, http://dx.doi.org/10.1001/jama.1988.03410070073031.

9. O'Connor GT, Buring JE, Yusuf S, Goldhaber SZ, Olmstead EM, Paffenbarger RS, et al. An overview of randomized trials of rehabilitation with exercise after myocardial 
infarction. Circulation. 1989;80(2):234-44, http://dx.doi.org/ 10.1161/01.CIR.80.2.234.

10. Taylor RS, Brown A, Ebrahim S, Jolliffe J, Noorani H, Rees K, et al. Exercise-based rehabilitation for patients with coronary heart disease: Systematic review and meta-analysis of randomized controlled trials. Am J Med. 2004;116(10): 682-92, http://dx.doi.org/10.1016/j.amjmed.2004.01.009.

11. Ceci V, Chieffo C, Giannuzzi P, Boncompagni F, Jesi P, Schweiger $\mathrm{C}$, et al. [Standards and guidelines for cardiac rehabilitation. Working Group on Cardiac Rehabilitation of the European Society for Cardiology]. Cardiologia. 1999;44(6):579-84. Italian.

12. Scafa F, Calsamiglia G, Tonini S, Lumelli D, Lanfranco A, Gentile E, et al. Return to work after coronary angioplasty or heart surgery: A 5-year experience with the "CardioWork" protocol. J Occup Environ Med. 2012;54(12):1545-9, http://dx.doi.org/10.1097/JOM.0b013e3182677d54.

13. Ainsworth BE, Haskell WL, Herrmann SD, Meckes N, Bassett Jr DR, Tudor-Locke C, et al. The Compendium of physical activities tracking guide [Internet]. Arizona State University and National Cancer Institute; 2012 [cited 2015 Mar 23]. Available from: https://sites.google.com/site/compendiumofphysicalactivities.

14. Rabin R, de Charro F. EQ-5D: A measure of health status from the EuroQol Group. Ann Med. 2001;33:337-43, http:// dx.doi.org/10.3109/07853890109002087.

15. Schweikert B, Hahmann H, Leidl R. Validation of the EuroQol questionnaire in cardiac rehabilitation. Heart. 2006;92(1):62-7, http://dx.doi.org/10.1136/ hrt.2004.052787.

16. Pickard AS, Kohlmann T, Janssen MF, Bonsel G, Rosenbloom S, Cella D. Evaluating equivalency between response systems: Application of the Rasch model to a 3-level and 5-level EQ-5D. Med Care. 2007;45:812-9, http://dx.doi. org/10.1097/MLR.0b013e31805371aa.

17. Balestroni G, Omarini G, Omarini P, Zotti AM. [EuroQol5D FOR quality of life assessment in cardiac rehabilitation]. G Ital Med Lav Ergon. 2007;29(3):B56-62. Italian.
18. Zigmond AS, Snaith R. The hospital anxiety and depression scale. Acta Psychiatr Scand. 1983;67(6):361-70, http:// dx.doi.org/10.1111/j.1600-0447.1983.tb09716.x.

19. Snaith R. The hospital anxiety and depression scale. Health Qual Life Outcomes. 2003;1:29-32, http://dx.doi. org/10.1186/1477-7525-1-29.

20. Jette AM, Davies AR, Cleary PD, Calkins DR, Rubenstein LV, Fink A, et al. The Functional Status Questionnaire: Reliability and validity when used in primary care. J Gen Intern Med. 1986;1(3):143-9, http://dx.doi.org/10.1007/ BF02602324.

21. McBurney CR, Eagle KA, Kline-Rogers EM, Cooper JV, Smith DE, Erickson SR. Work-related outcomes after a myocardial infarction. Pharmacotherapy. 2004;24(11):1515-23, http://dx.doi.org/10.1592/phco.24.16.1515.50946.

22. Abbas AE, Brodie B, Stone G, Cox D, Berman A, Brewington $S$, et al. Frequency of returning to work one and six months following percutaneous coronary intervention for acute myocardial infarction. Am J Cardiol. 2004;94(11):1403-5, http://dx.doi.org/10.1016/j.amjcard.2004.08.014.

23. Pinto N, Shah P, Haluska B, Griffin R, Holliday J, Mundy J. Return to work after coronary artery bypass in patients aged under 50 years. Asian Cardiovasc Thorac Ann. 2012;20(4): 387-91, http://dx.doi.org/10.1177/0218492312437881.

24. Yonezawa R, Masuda T, Matsunaga A, Takahashi Y, Saitoh M, Ishii A, et al. Effects of phase II cardiac rehabilitation on job stress and health-related quality of life after return to work in middle-aged patients with acute myocardial infarction. Int Heart J. 2009;50(3):279-90, http://dx.doi. org/10.1536/ihj.50.279.

25. Waszkowska M, Szymczak W. Return to work after myocardial infarction: A retrospective study. Int J Occup Med Environ Health. 2009;22(4):373-81, http://dx.doi.org/10.2478/ v10001-009-0033-4.

26. De Rosa R, Ratti G, Lamberti M. Onset of recent exertional dyspnoea in firefighter with left bundle-branch block. BMJ Case Rep. 2014;28, http://dx.doi.org/10.1136/bcr-2014207424. 
27. Korzeniowska-Kubacka I, Piotrowicz R. [Cardiological rehabilitation: A chance of returning to work]. Med Pr. 2005;56(4):325-7. Polish.

28. Isaaz K, Coudrot M, Sabry MH, Cerisier A, Lamaud M, Robin C, et al. Return to work after acute ST-segment elevation myocardial infarction in the modern era of reperfusion by direct percutaneous coronary intervention. Arch Cardiovasc Dis. 2010;103(5):310-6, http://dx.doi.org/10.1016/j.acvd. 2010.04.007.

This work is available in Open Access model and licensed under a Creative Commons Attribution-NonCommercial 3.0 Poland License - http://creativecommons.org/ licenses/by-nc/3.0/pl/deed.en. 